\title{
Enterprise Internal Audit Risk and Its Prevention
}

\author{
Gao Yurong \\ Shandong Women's University \\ Jinan 250300, Shandong, China
}

\begin{abstract}
The complexity of the economic environment, the expansion of the scale of enterprises, the diversification of economic entities, result in increasing business risk. Therefore, the prevention and control of internal audit risk is particularly important. This paper mainly analyzes the causes of the current internal audit risk of enterprises through the investigation, and points out that the existences of problems such as the weak audit risk consciousness of enterprise management and internal auditors and irrational internal audit institution settings have caused internal audit risk. On this basis, it is proposed to enhance the awareness of internal audit risk prevention, enhance the independence of the audit institutions, create a good internal audit environment of enterprise, and strengthen the training and management of internal audit staff. Select the appropriate audit procedures and audit methods and other preventive measures, expecting to enable the internal audit of the enterprise to play its proper role.
\end{abstract}

Keywords_-internal audit risk; reason; precautionary measures

\section{INTRODUCTION}

Internal audit risk refers to the possibility that the internal audit staff fail to timely detect the major problems or defects in the management and internal control of the audited units due to various subjective or objective reasons in the implementation of the statutory duties of internal audit supervision, and reach to inaccurate audit conclusions on audit matters.[1] With the continuous development of economy and society, the social requirements for enterprise management are getting higher and higher. As an important part of the business management process, internal audit work is facing great challenges. To control and prevent internal audit risk is an important content to improve the quality of audit work. If the enterprise does not control the internal audit risk, it is bound to lead to audit results deviating from the actual situation of the enterprise, which not only can't supervise the internal business, but also will induce information decision makers to make the wrong economic decision. Therefore, preventing internal audit risk is the fundamental of enterprise internal management.

\section{WHAT CAUSES THE RISKS IN THE ENTERPRISE INTERNAL AUDIT PROCESS}

\section{A. Weak audit risk awareness of the management and internal audit staff}

In the internal audit work, the enterprise management pays more attention to the carrying out of internal audit work, but ignores the risk of internal audit. They believe that there is almost no risk in internal audit, audit risk only occurs in the external audit. The company internal audit staffs are affiliated with the company, and have established labor contract relations with the company, so the internal audit staffs do not need to bear the economic responsibility, therefore there is no risk at all The management's neglect has also led to the weak risk awareness of the internal audit staff. The inadequate supervision of internal audits, coupled with limited levels of internal audit staff, prevents the forming of risk prevention consciousness in a short period and results in large internal audit risks and vulnerabilities.

\section{B. Irrational internal audit institution settings}

The irrational set of internal audit institutions is the most important reason to contain the internal audit, and is also one of the most fundamental reasons that affect the authenticity of internal audit. Most of the enterprise internal audit departments in China are in a very embarrassing situation, lack of independence. Many companies haven't set up independent internal audit department, and have no full-time audit staff. Some enterprises set the internal audit in the discipline inspection and supervision departments or financial departments. The internal audit staff not only need to engage in discipline inspection, but also need to do internal audit, or do financial review when it is set in the financial department. Leaders not only are responsible for discipline inspection and financial work, but also need to be responsible for internal audit work. Therefore, it is difficult for the unit's internal audit to stand in an objective and impartial position and make a very accurate and appropriate evaluation of the unit's economic activities. Especially when the leaders have low quality and limited management level, and are also involved in violations, the internal audit is often powerless. It may issue some false audit report, which buries huge hidden danger and results in large audit risk. These are all caused by the relative independence of internal audit. With relative independence, when audit authorization or principal's control on audit people become weaker and weaker, the audit risk is becoming higher and higher.

\section{The business scope of enterprise has been expanding and complicated}

With the expansion of enterprise's business scope, the audit business volume also increases, and the internal audit is facing more and more difficulties. Different types of business require different types of audit business; enterprise-related system is becoming more and more complicated because of different financial derivatives, which makes the internal audit work facing many difficulties and increases audit risks. The audit scope of the enterprise has been expanded to the auditing of financial cost, assessment of enterprise's future operation 
ability and the auditing of the economic responsibility of the enterprise. It requires the audit staff to have strong practicing ability, which may lead to the audit risk.

\section{Audit staff's limitation on expertise and ability}

An important reason for the formation of audit risk is the limitation of expertise and ability of the audit staff. The internal audit work involves all aspects of the enterprise. It requires the auditors not only to have the relevant audit knowledge, but also to have the comprehensive management knowledge and seek benefit in the management of enterprise's operating process. It will also increase audit risk when audit staff are lack of expertise and audit experience, not familiar with enterprise's internal control relationship and operating, and have single knowledge structure. At the same time, the internal audit staff may come to badly distorted audit conclusion because their relationship with the audited unit or personal reasons, resulting in audit risk.[2]

\section{E. Choose inappropriate audit procedures and methods}

There are more and more information needed to be audited in modern audit. Whether the procedures and methods adopted are scientific and applicable directly affects the quality of the audit and forms audit risk. Due to the different actual situation of the audited units, they have different audit purpose. Whether the procedures and methods adopted in audit are appropriate can only be judged subjectively. It's difficult to guarantee their appropriacy. The internal audit methods of some enterprises are very single, the internal audit staff only audit by checking document records and tangible assets, and more are the method of manual checking, which can only ensure the accuracy and integrity of financial records, and do not often use other auditing procedures such as analytical procedures. Especially for audit projects which are very procedural and complicated, if adopting inappropriate auditing procedures and methods, it will miss some important audit content and misjudge some auditing content, resulting in the inconsistency of audit conclusion and the real situation. In addition, the internal audit tends to use sampling audit. The inherent defect of sampling technology itself will affect the accuracy of the overall audit result judgment. The inevitable risk of sampling risk will also lead to errors in the audit results, resulting in increased audit risk.

\section{MEASURES TO PREVENT INTERNAL AUDIT RISK}

\section{A. Enhance the prevention awareness of internal audit risk}

Internal audit is a behavior integrating professional and technical natures. To do a good job of audit risk prevention and control, we must first raise the risk prevention awareness of the internal audit staff. Internal auditors should understand the audit risk in depth from the ideological and conceptual perspectives. In the process of designing the audit procedure and selecting the audit method, the audit risk should be fully considered and the risk awareness of the internal audit staff should be strengthened. Through the comprehensive analysis of the audit risk, help audit staff correctly understand the audit risk and develop their sense of risk.[3] The internal audit staff must let the audit risk consciousness run through the whole process of audit plan, audit implementation and audit completion. In addition, they need to establish a good internal operating mechanism, and constantly improve the internal quality control system. They should build a timely and effective risk control mechanism, providing protection for the effectiveness of the audit work.

\section{B. Enhance the independence of audit institutions setting}

The structure of the organization can directly affect the work method and efficiency of a department. The internal audit department is even more so. The most important thing for improving the internal audit institutional settings is to maintain the independence of internal audit department. Large units must set up special internal audit institutions, and audit institutions should belong to high-level department, and at the same time allocate specialized audit personnel to engage in audit activities. If the unit size is relatively small and it must be equipped with internal audit staff, the internal audit can be set up in the discipline inspection and supervision department, but must be equipped with full-time financial professionals specializing in internal audit. At the same time the audit department should have special funds, so as to ensure internal audit's independence on staff, work and funds. Ensure that the internal audit department's rights and obligations are independent from the enterprise executives. In the internal audit, the internal audit department can unconditionally conduct economic responsibility audit on the enterprise executives, and directly process or submit it to the discipline inspection department if the audit has found problem. Unit leaders should also pay attention to the internal audit work, and let the internal audit institutions and personnel have certain authority to ensure that they are in a detached position to carry out internal audit activities, so that the internal audit work can be less interfered by external factors and reduce the occurrence of internal audit risk.[4]

\section{Create a good internal audit environment}

Enterprises must create a good internal audit environment. Only in this way can reduce the audit risk more effectively. First of all, enterprise should ensure the openness and impartiality of the internal audit environment, and ensure that the internal auditors will adhere to the principle of independent, impartial and objective in the course of carrying out audit work and ensure the quality of internal audit work. Second, the enterprise should establish a corresponding internal audit management system, so that internal audit staff can have a sense of responsibility in the audit work and have some principles to adhere to, avoid audit staff muddling through their work. The audit staff is able to understand the importance of their work in this way. At last, the audit department should establish a fair and reasonable staff promotion system based on academic qualifications, practice level, job evaluation and work attitude, encourage audit staff to continuously improve their own business quality, laying a solid theoretical foundation and practice basis for the implementation of the audit work. This will mobilize the enthusiasm of the audit staff to a certain extent, and effectively avoid audit risk caused by human factors.[5] 


\section{Strengthen the internal audit staff training and management.}

In order to strengthen and prevent the internal audit risk control, enterprises should continue to improve the training and management of internal audit staff. First of all, enterprises should establish and improve the internal audit staff behavior standard, including professional discipline, professional ethics, professional responsibility, and professional competence and so on. The internal auditors can be competent for the internal audit work only if they follow the code of conduct and have good professional ethics. Only when the audit staff completes the audit work reasonably and legally can reduce the possibility of audit risk. Second, train the basic financial data processing skills of internal audit staff, which can allow them to effectively analyze the financial data and form basic audit abilities. The enterprise should constantly enrich the knowledge reserve of internal audit staff, including business knowledge, information technology knowledge, accounting, auditing and related knowledge, risk management knowledge and so on. Third, internal audit staff should have certain personal skills such as skills and application skills, personal skills, communication and coordination skills, learning ability, innovation ability, strategic management ability, risk management ability, etc., and be able to use audit tools such as risk management tools, information technology software and application tools for audit work.[6]

\section{E. Select the appropriate audit procedures and audit methods}

Audit staff should establish a standardized audit procedure when conducting internal audits, and use the risk-oriented audit method to determine the focus of the audit work. They can also use the computer audit technology to improve the audit procedure and standardize the audit process through the establishment and improvement of the information audit operating system. Combined with the business model and specific circumstances, conduct dynamic tracking and monitoring on the operation of the enterprise, and give timely warning of the risks that may exist in the operation and management of the enterprise. Timely communicate with the enterprise management about the company's operating conditions, better playing the supervision and service functions of internal audit.
In the audit methodology, the risk-oriented risk basic audit should be used. Develop strategy on the basis of the systematic analysis and evaluation of the audit risk. The audit staff should not only evaluate the control of risk, but also need to evaluate the various aspects that may occur risks, so as to determine the focus and test level of audit staff's substantive test, and determine how to collect, how much to collect and what kind of evidence to collect. Risk basic audit can also assess the risk of audited unit and find high-risk audits, so as to focus on maximumly reducing audit risk and improving audit efficiency, eventually reducing audit risk to an acceptable level.

\section{CONCLUSION}

Internal audit risk runs through the whole internal audit work. The internal audit risk prevention and control can't be separated from the mutual cooperation and support of internal audit staff, relevant departments and audited units. Internal audit staff of enterprise should understand the audit risk from the ideological and conceptual perspectives, pay attention to the audit risk and enhance the awareness of risk prevention. Management should set up audit institutions rationally to ensure the independence of internal audit. In the implementation of the audit business, audit staff should continue to enhance their professional competence, select appropriate audit procedures and audit methods to improve the efficiency and work quality of the audit, so as to actually play the role of internal audit and promote the healthy and sustainable development of the enterprise.

\section{REFERENCES}

[1] Chen Hui. How to Avoid Audit Risk in Internal Audit [J]. China Chief Accountant, 2012 (02)(In Chinese)

[2] Zhang Wei. Causes and Prevention of Internal Audit Risks [J] Journal of Nanjing Institute of Auditing, 2011 (10) (In Chinese)

[3] Wang Zhikai. Study on Auditing Risks of Listed Companies and Countermeasures [J]. Journal of Enterprise Reform and Management, 2014, (12) (In Chinese)

[4] Li Xiaoqiao. Study on the Cause and Countermeasure of Internal Audit Risk in Enterprise [J]. Internal Control and Auditing, 2015 (04) (In Chinese)

[5] Xiong Chunhua.Study on Enterprise Internal Audit Risk Management [J]. Enterprise Reform and Management, 2016 (07). (In Chinese)

[6] Wu Dan. Study on the Causes and Preventive Measures of Enterprise Internal Audit Risk [J] .Enterprises Manager, 2016 (01). (In Chinese) 